\title{
Sleep Changes with Aging
}

\author{
*AKMY Halim ${ }^{1}$ \\ 1AKMY Halim, Vice Principal, Army Medical College, Bogra, Bangladesh \\ *Corresponding Author
}

Date of submission: 24 November 2014 Date of acceptance: 03 March 2015

\begin{abstract}
Sleep disorders and sleeping difficulty are poorly-addressed problems of aging. Research has shown that as many as $50 \%$ of older adults complain about difficulty in initiating or maintaining sleep. Elderly with varieties of sleep complaints are differentially affected by 'age-related cognitive decline'. Normal developmental processes have been affected with changes in sleep, which can be further compromised by sleep disturbances secondary to medical or psychiatric diseases such as chronic pain, depression, dementia or age-related primary sleep disorders (e.g., sleep disordered breathing and periodic limb movements during sleep), or certain combinations of these high-risk factors. Sleep serves as a protective mechanism to keep the organism out of danger; therefore, it is imperative to consider sleep disorders for quality life. The evaluation of these disorders is discussed in this review.
\end{abstract}

Key Words: Ageing, Sleep changes, Sleep-disordered breathing

\section{Introduction}

Sleep problems appear to be widespread among the elderly ${ }^{1-2}$. Patients with sleeping difficulties report decreased quality of life and endorse more symptoms of depression and anxiety when compared to those without sleep difficulties. Evidence showed that inadequate sleep is associated with significant morbidity and mortality in older adults $^{3}$. The prevalence of sleep-related breathing disorder (SRBD) and insomnia symptoms increases considerably with advancing age, but little is known about their co-occurrence and their effects ${ }^{4-6}$. They are at greater risk for decreased physical functioning, increased risk of work related accidents and problems with memory 4 .

Etiology is complex, involving multiple factors, such as neurodegenerative changes in the brain, the patient's environment, medical or psychiatric morbidity, and medications used to treat chronic illnesses $^{2,7}$. Risk factors for sleeping difficulty in the elderly are depression, respiratory symptoms, disability, and fair to poor perceived health, and use of prescribed sedatives. The relationship between sleep disturbance and depression in the elderly is especially strong. Untreated insomnia may result in depression and the presence of a depressed mood may even predict insomnia. It is difficult to determine whether depression causes insomnia or vice versa ${ }^{8-9}$, in a study of 7954 respondents by Ford and Kamerow suggests that unremitting insomnia causes depression ${ }^{10}$. This decreased ability to sleep is often as a function of co-morbidities associated with aging, rather than with aging per $\mathrm{se}^{11}$. A variety of age-related comorbid conditions that exacerbate sleep disturbances such as ischemic heart disease, diabetes, depression, renal failure, arthritis, and pulmonary disorders and the multiple medications used to treat them are common in the older adult population and enhance risk for development of insomnia ${ }^{7,12-14}$. Narcotic analgesics routinely used to control chronic pain can cause excessive daytime sleepiness (EDS) ${ }^{15}$.

\section{Dementia}

Dementia is a neurodegenerative disorders (e.g., Alzheimer's disease, Parkinson's disease). It affects memory, thinking, language, judgment, and behavior. Behavioral disturbances are exhibited in almost all people with dementia. Common behavioral disturbances are mood disorders (e.g., depression, apathy, euphoria); sleep disorders 
(insomnia, hypersomnia, night-day reversal); psychotic symptoms (delusions and hallucinations); and agitation (e.g., pacing, wandering, sexual disinhibition, aggression). They are often persistent; greatly diminish quality of life of patients and their family caregivers ${ }^{16}$. Reports suggest that $19-44 \%$ of community-dwelling patients with dementia complain about sleep disturbances such as circadian rhythm changes, medical illnesses, depression and the primary sleep disorders ${ }^{17}$.

\section{Medical and Psychiatric Illnesses}

Insomnia is difficulty in getting to sleep or staying asleep for long enough to feel refreshed on the next morning, even though he/she have had enough opportunity to sleep ${ }^{18}$. Studies showed that sleep disturbances in patients with chronic medical diseases such as arthritis, chronic pain, diabetes etc report difficulty in falling and/or staying asleep. Other health-related diseases those are associated with insomnia include congestive heart failure, cancer, nocturia, shortness of breath due to chronic obstructive pulmonary disease, neurological deficits related to cerebrovascular accidents, and Parkinson's disease ${ }^{7}$. Ohayon and Roth ${ }^{19}$ conducted a large cross-sectional survey and observed that in $65 \%$ of those with major depression, $61 \%$ with panic disorder and $44 \%$ with generalized anxiety disorder also suffered from insomnia. Perlis et al. ${ }^{20}$ also described that insomnia is a significant risk factor for recurrent and a new onset of major depressive disorder especially for the elderly subjects, particularly women, were at greater risk for the development of depression. The annual incidence rate of insomnia in 65 years or older is approximately $5 \% 21$.

While medications are traditionally used to treat insomnia, however, recent studies have shown that behavioral treatments are more effective and, thus, recommended as the first-line treatment option. Others treatment involves a combination of sleep restriction therapy, stimulus control therapy, relaxation techniques and good sleep hygiene practices $^{22}$.

\section{Circadian Rhythm Changes}

As people older, their circadian rhythms become weaker, desynchronized and lose amplitude.
AKMY Halim

Changes in the phasing of the circadian rhythm develop in older adults which can cause changes in the timing of the sleep period. The amplitude of the circadian rhythm decreases with age. In turn, this reduction can increase the frequency of nighttime awakenings and the severity of daytime sleepiness ${ }^{23}$. Nocturnal secretion of endogenous melatonin that also plays an important role in the sleep-wake cycle gradually decreases with age, possibly resulting in reduced sleep consolidation, duration and early morning awakenings ${ }^{23}$. Light exposure, social and activity rhythms has been demonstrated as the most powerful contributing to circadian entrainment in humans to the 24-h day ${ }^{24-25}$.

\section{Primary Sleep Disorders and Aging}

Mental disorders, medical conditions, medications or substance use are not counted as the primary sleep disorders. The most common primary sleep disorder in the elderly population is: sleepdisordered breathing. Sleep-Disordered Breathing (SDB) describes a range of respiratory events that occur periodically during sleep, from simple snoring to complete cessation of airflow (apnea) at the more severe end. Snoring is the sound caused by the vibration of the uvula and soft palate due to obstructed air movement during breathing while sleeping. It plays a role in the breathing cessation during an apnea event and approximately 50 per cent of those who snore also have $\mathrm{SDB}^{26}$. The number of instances of apnea and hypopnea (partial reduction in airflow) per hour of sleep is called the Apnea-Hypopnea Index (AHI). For SDB diagnosis, a patient has an AHI $>5-10$. Sleep-disordered breathing is more prevalent in the older population and even more common in elderly nursing home patients, especially among those who suffer from dementia $^{27-30}$. Risk factors for SDB include: age, gender and obesity. Other conditions that increase the risk of developing SDB include: the use of sedating medications, alcohol consumption, family history, race, smoking and upper airway configuration. The main symptoms of SDB in the elderly population are snoring and EDS. The Sleep Heart Health Study found that the risk of developing cardiovascular disease, including coronary artery disease, congestive heart failure and stroke, is positively related to the severity of SDB ${ }^{31-33}$. 
The most common and proven treatment for SDB is continuous positive airway pressure (CPAP). Patients with sleep apnea-hypopnea syndrome treated with CPAP have improved daytime function, alertness and quality of life $^{34}$. Following CPAP treatment; older adults have increased neurobehavioral outcomes in cognitive function, memory and have more consolidated sleep. Moreover, a positive effect for CPAP user observed on the factors affecting the cardiac functions included vascular resistance, platelet coagulability and other aspects of cardiovascular health. Therefore, the SDB treatment needs to be considered as an important and urgent regardless of the age $\mathrm{e}^{35-36}$.

Other important primary sleep disorders are restless legs syndrome/periodic limb movements in sleep (RLS/PLMS) and Rapid Eye Movement SleepBehavior Disorder (RBD).

\section{Restless Legs Syndrome/Periodic Limb Movements in Sleep}

Restless Legs Syndrome (RLS) is an uncomfortable sensation in legs accompanied by urge to move that occurs in a relaxed awake or restful state and, thus, is more common during the evening or at night. Movement provides temporary relief of this uncomfortable sensation. Other terms that are used to describe this sensation include: creepy-crawly, electric current, crazy legs, worms moving, ants crawling or pain ${ }^{37}$. The development of secondary RLS is associated with renal failure, iron deficiency, frequent blood donation, Parkinson disease, neuropathy, as well as pregnancy. Generally, these medical conditions are more frequently complicated in patient with RLS than in healthy controls ${ }^{38}$.

Periodic Limb Movements in Sleep (PLMS) are characterized by clusters of repetitive leg jerks or kicks causing brief arousal and/or awakening occurring approximately every $20-40 \mathrm{sec}$ over the course of a night during sleep. PLMS is diagnosed with an overnight sleep recording (polysomnogram) which shows patients having at least 5 leg jerks per hour of sleep associated with arousal. It is often related to RLS and in the absence of RLS; there may be little clinical significance to PLMS. The prevalence of both RLS and PLMS increases significantly with age $^{39}$. The recommended treatments for RLS/PLMS are dopamine agonists for all age groups ${ }^{40}$.

\section{Rapid Eye Movement Sleep-Behavior Disorder (RBD)}

RBD is a condition in which the skeletal muscle atonia normally found in Rapid Eye Movement (REM) sleep is absent. The patient's uncontrolled movements like kicking, punching, running and/or yelling are found in sleep and sometimes it can be aggressive and/or violent, and might result in injuries either to the patient himself and/or the patient's bed partner. The etiology of chronic RBD is currently unknown; some data suggest that RBD may be the first manifestation and/or indication of a neurodegenerative disease 41 . Study showed that $50 \%$ of those diagnosed with RBD has developed Parkinson's disease or Multiple System Atrophy within 3-4 years ${ }^{42}$.

Among the common problems related to aging is sleep quality. Sleep disturbances that are frequently seen in people with neurologic disorders place significant stress on the functional status, changes in cognition and mood, and behavioral disruptions. In addition, sleep-disordered breathing is a common manifestation higher in older compared to middleaged adults resulting in an increased burden for families and caregivers associated with increases in overall health care costs. Careful health assessment in an individual with sleep disorders can improve the overall sleep problems for elderly in this population.

Table I: Some Wake-Promoting Agents ${ }^{43}$

\begin{tabular}{|c|c|c|c|c|}
\hline MEDICATION & DOSE (MG) & $\begin{array}{l}\text { COMMON SIDE } \\
\text { EFFECTS }\end{array}$ & $\begin{array}{l}\text { SERIOUS SIDE } \\
\text { EFFECTS }\end{array}$ & $\begin{array}{l}\text { CONTRA } \\
\text { INDICATIONS } \\
\text { AND } \\
\text { PRECAUTIONS }\end{array}$ \\
\hline $\begin{array}{l}\text { Amphetamine/ } \\
\text { dextroamphetamine } \\
\text { IR (Adderall) }\end{array}$ & $5-60$ & $\begin{array}{l}\text { Weight loss, } \\
\text { headache, insomnia, } \\
\text { tremor, abdominal } \\
\text { pain, anorexia, } \\
\text { xerostomia, } \\
\text { euphoria, nervous, } \\
\text { restlessness }\end{array}$ & $\begin{array}{l}\text { Cardiomyopathy, } \\
\text { chest pain, MI, } \\
\text { irregular heart rate, } \\
\text { immune } \\
\text { hypersensitivity } \\
\text { reaction, CVA, } \\
\text { CNS stimulation, } \\
\text { psychotic disorder } \\
\text { with prolonged use, } \\
\text { sudden death, }\end{array}$ & $\begin{array}{l}\text { Advanced } \\
\text { arteriosclerosis, } \\
\text { hyperthyroidism, } \\
\text { severe } \\
\text { hypertension }\end{array}$ \\
\hline $\begin{array}{l}\text { Methylphenidate } \\
\text { hydrochloride } \\
\text { (Ritalin, Concerta) }\end{array}$ & $10-60$ & $\begin{array}{l}\text { Loss of appetite, } \\
\text { abnormal behavior, } \\
\text { restlessness }\end{array}$ & $\begin{array}{l}\text { Hypertension } \\
\text { (frequent), } \\
\text { tachyarrhythmia } \\
\text { (frequent), } \\
\text { thrombocytopenia, } \\
\text { hallucinations }\end{array}$ & $\begin{array}{l}\mathrm{H} / \mathrm{O} \text { drug } \\
\text { dependence or } \\
\text { alcoholism. Pts } \\
\text { taking MAOIs and } \\
\text { pts with glaucoma, } \\
\text { motor tics, } \\
\text { Tourette's } \\
\text { syndrome }\end{array}$ \\
\hline Modafinil (Provigil) & $200-800$ & $\begin{array}{l}\text { Headache, nausea, } \\
\text { anxiety nervousness, } \\
\text { insomnia, dizziness }\end{array}$ & $\begin{array}{l}\text { Hypersensitivity } \\
\text { syndrome, Stevens- } \\
\text { Johnson syndrome, } \\
\text { hypertension }\end{array}$ & $\begin{array}{l}\text { Angioedema, } \\
\text { hypersensitivity, } \\
\text { anaphylactoid } \\
\text { reaction }\end{array}$ \\
\hline
\end{tabular}

avg, average; CNS, central nervous system; CVA, cerebrovascular accident; MAO, monoamine oxidase; MAOI, monoamine oxidase inhibitor; MI, myocardial infarction; 
Talbe II: Some Hypnotic Drugs Used in the Treatment of Insomnia ${ }^{44}$

\begin{tabular}{|c|c|c|c|c|}
\hline DRUG TYPE & MEDICATION & DOSE (MG) & SIDE EFFECTS & $\begin{array}{l}\text { CONTRA } \\
\text { INDICATIONS } \\
\text { AND } \\
\text { PRECAUTIONS }\end{array}$ \\
\hline \multirow{2}{*}{$\begin{array}{l}\text { Benzodiazepine } \\
\text { Hypnotics }\end{array}$} & $\begin{array}{l}\text { Nitrazepam } \\
\text { (Alodorm) }\end{array}$ & $5-10$ & $\begin{array}{l}\text { Drowsiness, dizziness, } \\
\text { visual disturbance, } \\
\text { hypersensitivity }\end{array}$ & \multirow{2}{*}{$\begin{array}{l}\text { Acute pulmonary } \\
\text { insufficiency, } \\
\text { respiratory } \\
\text { depression, } \\
\text { chronic psychosis }\end{array}$} \\
\hline & $\begin{array}{l}\text { Temazepam } \\
\text { (Restoril) }\end{array}$ & $15-30$ & $\begin{array}{l}\text { reactions, G I } \\
\text { disturbance, urinary } \\
\text { retention, dependency. }\end{array}$ & \\
\hline \multirow{2}{*}{$\begin{array}{l}\text { Nonbenzodiazepine } \\
\text { Hypnotics }\end{array}$} & $\begin{array}{l}\text { Zolpidem } \\
\text { (Ambien) }\end{array}$ & $\begin{array}{l}5-10 \\
\text { (age >65 yrs) }\end{array}$ & \multirow{2}{*}{$\begin{array}{l}\text { Daytime drowsiness, } \\
\text { dizziness, vertigo, } \\
\text { nightmare, confusion, } \\
\text { tremor, unsteady gait. }\end{array}$} & \multirow{2}{*}{$\begin{array}{l}\text { History of drug or } \\
\text { alcohol use, } \\
\text { tolerance, } \\
\text { amnesia, } \\
\text { psychiatric } \\
\text { reations. }\end{array}$} \\
\hline & $\begin{array}{l}\text { Zopiclone } \\
\text { (Imovane) }\end{array}$ & $\begin{array}{l}3.75 \\
\text { (age > 65 yrs) }\end{array}$ & & \\
\hline \multirow{2}{*}{$\begin{array}{l}\text { Nonhypnotics } \\
\text { Sometimes Used to } \\
\text { Aid Sleep }\end{array}$} & $\begin{array}{l}\text { Clonazepam } \\
\text { (Klonopin) }\end{array}$ & $0.5-3$ & \multirow{2}{*}{$\begin{array}{l}\text { Muscle hypotonia, } \\
\text { coordination } \\
\text { disturbances, mental } \\
\text { change. }\end{array}$} & \multirow{2}{*}{$\begin{array}{l}\text { Respiratory } \\
\text { depression, Acute } \\
\text { pulmonary } \\
\text { insufficiency }\end{array}$} \\
\hline & $\begin{array}{l}\text { Diazepam } \\
\text { (Valium) }\end{array}$ & $2-10$ & & \\
\hline
\end{tabular}

Table III: Other Drugs Used to Treat Insomnia ${ }^{44}$

\begin{tabular}{lccll}
\hline Drug & Drug Type & Dose (Mg) & Side Effects & $\begin{array}{c}\text { Contra hdications and } \\
\text { Precautions }\end{array}$ \\
\hline Melatonin & Hormone & $3-6$ & Headach, depression & Autoimmune diseases \\
Diphenhydramine & $\begin{array}{l}\text { Ethanolamine } \\
\text { antihistamine }\end{array}$ & $50-75$ & $\begin{array}{l}\text { Drowsiness, dryness of of } \\
\text { mouth \& skin }\end{array}$ & $\begin{array}{l}\text { Alcohol \& other CNS } \\
\text { depressants }\end{array}$ \\
Gabapentin & Anticonvulsant & 900 & Fatigue, we ight gain, ataxia & $\begin{array}{l}\text { Known hypersensitivity } \\
\text { drug }\end{array}$ \\
\hline
\end{tabular}

\section{Conflict of interest: absent}

\section{References}

1. Roepke SK, Ancoli-Israel S. Sleep disorders in the elderly. Indian J Med Res 2010;

131: 302-10.

2. Harrington JJ, Lee-Chiong T Jr. Sleep and older patients. Clin Chest Med 2007; 28(4): 673-84.

3. Rockwood K, Davis HS, Merry HR, MacKnight C, McDowell I. Sleep disturbances and mortality: results from the Canadian Study of Health and Aging. J Am Geriatr Soc 2001; 49(5): 639-41.

4. Gooneratne NS, Gehrman PR, Nkwuo JE, Bellamy SL, Schutte-Rodin S, Dinges DF, et al. Consequences of comorbid insomnia symptoms and sleep-related breathing disorder in elderly subjects. Arch Intern Med 2006; 166(16): 1732-8.

5. Martin J, Stepnowsky C, Ancoli-Israel S: Sleep apnea in the elderly; In: McNicholas WT, Phillipson EA (eds): Breathing Disorders During Sleep. London, W.B. Saunders Company Ltd, 2002, pp 278-87.

6. Gülbay BE, Acican T, Onen ZP, Yildiz OA, Baççio?lu A, Arslan F, et al. Health-related quality of life in patients with sleep-related breathing disorders: relationship with nocturnal parameters, daytime symptoms and co-morbid diseases. Respiration 2008; 75(4): 393-401.
7. Foley D, Ancoli-Israel S, Britz P, Walsh J. Sleep disturbances and chronic disease in older adults: results of the 2003 National Sleep Foundation Sleep in America Survey. J Psychosom Res 2004; 56: 497-502.

8. Cole MG, Dendukuri N: Risk factors for depression among elderly community subjects: a systematic review and meta-analysis. Am JPsychiatry 2003; 160: 1147-56.

9. Chen YS. Association between chronic insomnia and depression in elderly adults. J Chin Med Assoc 2012; 75(5): 195-6

10. Ford DE, Kamerow DB. Epidemiologic study of sleep disturbances and psychiatric disorders. An opportunity for prevention? J Am Med Assoc 1989: 1479-84.

11. Neikrug AB, Ancoli Israel S.Sleep disorders in the older adult - a mini-review. Gerontology 2010; 56(2): 181-9.

12. Jang Y, Shin J, Cho S, Kim G, Chiriboga DA. The interactive role of chronic medical conditions and sleep disturbance in predicting depressive symptoms among Korean American older adults. Aging Ment Health. 2011; 15(2): 198-203.

13. Vitiello MV, MoeKE, Prinz PN. Sleep complaints cosegregate with illness in older adults: clinical research informed by and informing epidemiological studies of sleep. J Psychosom Res 2002; 53(1): 555-9.

14. Martin J, Shochat T, Ancoli-Israel S. Assessment and treatment of sleep disturbances in older adults. Clin Psychol Rev 2000; 20(6): 783-805.

15. Koehler U, Augsten M, Cassel W, Jerrentrup A, Nolte J, Dette F. Sleep-disordered breathing in long-term opioid therapy. Dtsch Med Wochenschr 2010; 135(22): 1125-28.

16. Desai AK, Schwartz L, Grossberg GT. Behavioral Disturbance in Dementia. Curr Psychiatry Rep 2012 May 27. [PMID 22644311]

17. McCurry SM, Reynolds CF, Ancoli-Israel S, Teri L, Vitiello MV: Treatment of sleep disturbances in Alzheimer's disease. Sleep Med Rev 2000; 4: 603-28.

18. American Academy of Sleep Medicine. The International Classification of Sleep Disorders. 2nd ed. Westchester (IL): The Academy; 2005.

19. Ohayon MM, Roth T: What are the contributing factors for insomnia in the general population? J Psychosomatic Res 2001; 51: 745-55.

20. Perlis ML, Smith LJ, Lyness JM, Matterson SR, Pigeon $\mathrm{WR}$, Jungquist $\mathrm{CR}$, et al. Insomnia as a risk factor for onset of depression in the elderly Behav. Sleep Med 2006; 4(2): 104-13.

21. Foley DJ, Monjan A, Simonsick EM, et al. Incidence and remission of insomnia among elderly adults: an epidemiologic study of 6,800 persons over 3 years. Sleep 22 (Suppl 2)1999; S366-72. 
Platelet Transfusion Therapy

22. Morin CM, Colecchi C, Stone J, Sood R, Brink D: Behavioral and pharmacological therapies for late life insomnia. JAMA 1999; 281: 991-9.

23. Brown SA, Schmitt K, Eckert A. Aging and circadian disruption: causes and effects. Aging (Albany NY) 2011; 3(8): 813-7.

24. Duffy JF, Kronauer RE, Czeisler CA. Phase-shifting human circadian rhythms: influence of sleep timing, social contact and light exposure. J Physiol (Lond ) 1996; 495(Pt 1): 289-97.

25. Mistlberger RE, Skene DJ. Social influences on mammalian circadian rhythms: animal and human studies. Biol Rev Camb Philos Soc 2004; 79: 533-56.

26. Collop NA, Cassell DK. Snoring and sleep-disordered breathing. In: Lee-Chiong TL, Sateia MJ, Carskadon MA, editors. Sleep Medicine. Philadelphia: Hanley \& Belfus; 2002. P.349-55.

27. Crowley K. Sleep and sleep disorders in older adults. Neuropsychol Rev. 2011; 21(1): 41-53.

28. Ancoli-Israel S, Gehrman P, Kripke DF, Stepnowsky C, Mason W, Cohen-Zion M, Marler M: Long-term follow-up of sleep disordered breathing in older adults. Sleep Med 2001; 2: 511-6.

29. Young T, Shahar E, Nieto FJ, Redline S, Newman AB, Gottlieb DJ, et al: Predictors of sleep-disordered breathing in community-dwelling adults: the Sleep Heart Health Study. Arch Intern Med 2002; 162: 893-900.

30. Young T, Palta M, Dempsey J, Skatrud J, Weber S, Badr S: The occurrence of sleep disordered breathing among middle-aged adults. N Engl J Med 1993; 328: 1230-35.

31. Launois SH, Pepin JL, Levy P: Sleep apnea in the eldelry: a specific entity? Sleep Med Rev 2007; 11: 87-97.

32. Shahar E, Whitney CW, Redline S, Lee ET, Newman $\mathrm{AB}$, Javier NF, et al: Sleep-disordered breathing and cardiovascular disease: cross sectional results of the Sleep Heart Health Study. Am J Respir Crit Care Med 2001; 163: 19-25.

33. Bassetti CL, Milanova M, Gugger M: Sleep-disordered breathing and acute ischemic stroke: diagnosis, risk factors, treatment, evolution, and long-term clinical outcome. Stroke 2006; 37: 967-72.

34. McArdle N, Douglas NJ. Effect of continuous positive airway pressure on sleep architecture in the sleep apneahypopnea syndrome: a randomized controlled trial. Am J Respir Crit Care Med 2001; 164: 1459-63.
35. Ayalon L, Ancoli-Israel S, Stepnowsky C, Palmer BW, Liu L, Loredo JS, et al: Adherence to continuous positive airway pressure treatment in patients with Alzheimer's disease and obstructive sleep apnea. Am J Geriatr Psychiatry 2006; 14: 176-80.

36. Weaver TE, Chasens ER: Continuous positive airway pressure treatment for sleep apnea in older adults. Sleep Med Rev 2007; 11: 99-111.

37. Allen RP, Picchietti DL, Hening WA, Trenkwalder C, Walters AS, Montplaisi J, Restless Legs Syndrome Diagnosis and Epidemiology workshop at the National Institutes of Health, International Restless Legs Syndrome Study Group: Restless legs syndrome: diagnostic criteria, special considerations, and epidemiology. A report from the restless legs syndrome diagnosis and epidemiology workshop at the National Institutes of Health. Sleep Med 2003; 4: 101-19.

38. Nomura T, Nakashima K. Prevalence of restless legs syndrome. Brain Nerve 2009; 61(5): 515-21.

39. Hornyak M, Feige B, Riemann D, Voderholzer U. Periodic leg movements in sleep and periodic limb movement disorder: prevalence, clinical significance and treatment. Sleep Med Rev 2006 Jun; 10(3): 169-77.

40. Hening W, Allen RP, Picchietti DL, Silber MH, Restless Legs Syndrome Task Force of the Standards of Practice Committee of the American Academy of Sleep Medicine: An update on the dopaminergic treatment of restless legs syndrome and periodic limb movement disorder. Sleep 2004; 27: 560-83.

41. Boeve BF, Silber MH, Ferman TJ, Lucas JA, Parisi JE: Association of REM sleep behavior disorder and neurodegenerative disease may reflect an underlying synucleinopathy. Mov Disorders 2001; 16: 622-30.

42. Olson EJ, Boeve BF, Silber MH: Rapid eye movement sleep behaviour disorder: demographic, clinical and laboratory findings in 93 cases. Brain 2000; 123: 331-9.

43. Mendenson W. Hypnotic medications: Mechanism of action and pharmacologic effects. In: Kryger MH, Roth T, Dement WC, editors. Principles and Practice of Sleep Medicine. Missouri: USA; 2011. pp. 484.

44. Nishino $\mathrm{S}$ and Mignot E. Wake-promoting medications: Efficacy and adverse effects.. In: Kryger MH, Roth T, Dement WC, editors. Principles and Practice of Sleep Medicine. Missouri: USA; 2011. pp. 532. 